\title{
A Critical Step to the Side: Performing the Loss of the Mother ${ }^{1}$
}

\author{
ELAINE ASTON
}

This essay sets out to ask in what ways it might be critically productive to come back to the maternal as a subject for feminism. Drawing on Eve Sedgwick's desire to 'loosen' the antiessentialist drive to get 'beyond' gender, and her consideration in this respect of a non-dualistic idea of 'beside', I locate my analysis in three performances, examined 'beside' each other. Each of these performances is a solo show: Anna Yen's Chinese Take Away (1997), SuAndi's The Story of M (1994) and Kazuko Hohki's Toothless (1998). Moreover, each solo is located in different inter-national, maternal geographies: Asian/Australian (Yen), black British (SuAndi) and Japanese/British (Hohki), and each performs the loss of the mother by the daughter. Working also with Judith Butler's proposal that grief and loss afford a political, transformative means of 'becoming undone', I 'read' these three international geographies of the maternal side by side as different from each other, but all connected to the critical project of rethinking the maternal.

\section{Coming back to mother?}

Motherhood has been a complex, often controversial feminist 'subject'. From maternal reclamation (and dissent) in second-wave feminism, through the problematic of her position in identity politics, to the trouble she poses for the possible 'freedoms' of moving beyond gender and identity that characterized influential gender theorizing in the 1990s, 'mother' has been 'difficult'. On the one hand, in the course of all of this critical activity important feminist attention has been paid to naming and resisting the histories and lived experiences of maternal and domestic oppressions. On the other, this has mapped complexly and, at times, controversially with various Western feminist attachments to the psychical mother and her relation to female identity and subjectivity.

Given this set of concerns, a question I am asking in this essay is, in what ways might it be critically productive to come back to the mother as a feminist subject? My interrogation of the maternal evolves through a consideration of three solo performances: Anna Yen's Chinese Take Away (1997), SuAndi's The Story of $M$ (1994) and Kazuko Hohki's Toothless (1998). Each solo locates in different inter-national, maternal geographies: Asian/Australian (Yen), Black British (SuAndi) and Japanese/British (Hohki), and each performs the loss of the mother by the daughter. 


\section{A festival of mothers}

The point at which I began to reflect critically on the possibilities of rethinking the maternal happened during the international women's theatre festival Roots in Transit, held at Odin Theatret, Hostelbro, Denmark (January 2004). ${ }^{2}$ Curated by Julia Varley, Roots in Transit was the fourth such festival in a series themed on aspects of women's performance and drawing on a long association with the international Magdalena Project and network. ${ }^{3}$ The thematic of Roots in Transit invited practitioners to present and discuss work that dealt with origins, identities not as something fixed or 'rooted', but as mobile, having the capacity to change. The festival brought together an international mix of women's theatre and performance work, and featured several solo pieces that focused on the mother figure. These included, for example, Gilla Cremer's (from Germany) solo reworking of Medea in her performance m.e.d.e.a, and two personal autobiographical solos: Looking for the Meaning by Gilly Adams (from Wales) and Ester's Book, a work in progress by Iben Nagel Rasmussen (from Odin). ${ }^{4}$

One of the ways in which 'roots' appeared 'in transit' was not just as a proposal in one work, or one discussion, but as a matter of seeing work and listening to discussions in relation to each other. Subsequently, I came to map this with Eve Sedgwick's desire to 'loosen' the antiessentialist drive to get 'beyond' gender; 'to explore promising tools and techniques for nondualistic thought and pedagogy'. ${ }^{5}$ With this in mind, Sedgwick proposes a consideration of 'beside', which she argues as an 'interesting preposition . . . because there's nothing very dualistic about it; a number of elements may lie alongside one another but not an infinity of them'. ${ }^{6}$ The 'besideness' of my viewings, seeing the shows together, in turn heightened the emotional charge of each individual performance. In the case of the maternal solos in particular, thinking motherhood arose as I saw the shows alongside each other: where each maternal point of contact was different to, though touched on, another; where the shows were not reductively relative to each other but through the performative 'roots' of the festival entered into a connecting and critical agenda. The emotional intensity of viewings that made me angry, that made me cry (and laugh) was what moved me to think critically about the mother figure.

'Being moved emotionally', feminist theatre scholar Jill Dolan argues, 'is a necessary precursor to political movement'. Passionate about the utopian possibilities that live performance may be able to offer, Dolan keeps 'faith in theatre's transformative impact on how we imagine ourselves [differently] in culture', and, moreover, cites the possibilities that may arise as 'temporary communities' are formed through the theatrical event. ${ }^{7}$ The festival experience reminded me of theatre's capacity to create emotional-political transformative spaces (as Dolan argues). As an event the festival proposed commonality (as a women's festival) and difference (as an international gathering), with theatre as the space for showing, encountering, contesting, reconsidering; it brought me into a 'temporary [women's] community' in which I was moved by the performance work to think otherwise. Specifically, as an international 'temporary [women's] community', the festival took me outside aspects of my own Western feminist thinking, and moved me towards the critical (maternal) analysis that follows. 


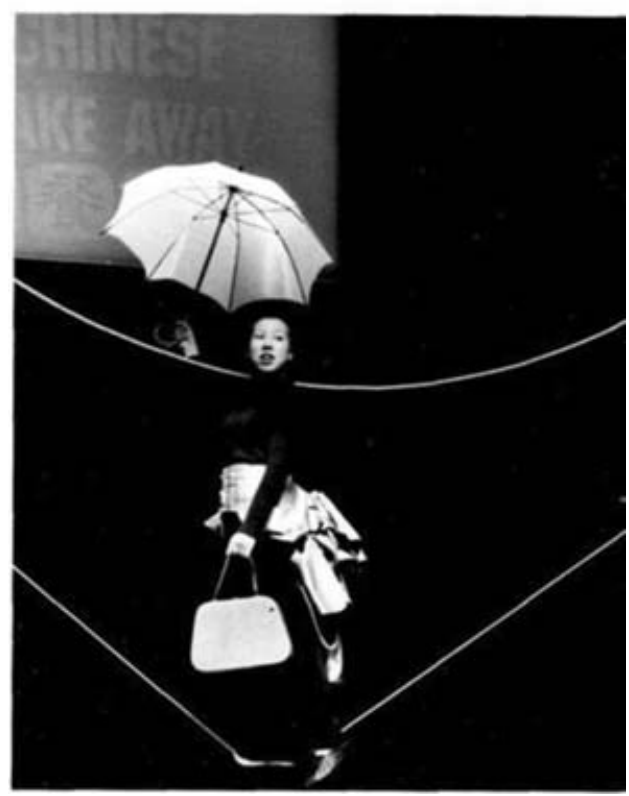

FIG. 1 Anna Yen performing in Chinese Take Away. Photograph (c) Reina Irmer.

Mirroring my experience of the festival, I move to present the three mother performances, each from different, international geographies of the maternal side by side: different from each other, but all connected to the critical project of rethinking the maternal. In brief, as a critical writing strategy, my hope is that discussion of these three performances charges readers with a similar (political) step to the side of those maternal attachments in order to help us, as Sedgwick would argue, to think 'otherwise'.

\section{Rethinking mother-child relations: Chinese Take Away}

It was in the context of the Transit Festival that I first encountered Chinese Take Away by Asian-Australian writer and performer Anna Yen. At the festival Yen performed an extract from the opening of the play, which was followed by a screening of the film version in which Yen, as in the stage production, plays all of the roles in the story of 'grandmother, mother and me'. The piece is written so that Yen makes constant switches between roles that she 'puts on' and 'takes off, mixing herself in (or messing herself up) with the other characters that all play parts in each other's stories. To perform Take Away Yen draws on her European training from the Le Coq tradition as well as circus skills, especially Chinese acrobatics. A hybridized mix of East and West also shapes the playing space - with Chinese silks, circus ropes, screen projections - and the writing of the piece that combines both Cantonese and English languages.

Chinese Take Away refers to the successful restaurant business of Yen's father in midtwentieth-century Australia, but also indexes the generational chain of children removed

\section{CAMBRIDGE}


from their families: sold as cheap labour. Anna's grandmother and father were both sold into child labour. ${ }^{8}$ Yen's mother was 'sold' in a different way. Her family arranged a marriage for her in Australia. As a young seventeen-year-old in the 1950s, she left Hong Kong believing she would be stepping off the plane into a new life as a student. Instead she walked into rape, pregnancy and marriage with Yen's father. ${ }^{9}$ The pain and violence of forced pregnancies and the racism of white Australian suburbia were responsible, Yen's biographical performance-telling suggests, for her mother's depression and, ultimately, suicide. One of the most 'shocking' moments of Chinese Take Away comes at the first suicide attempt as the teenage Anna comes home to find her mother's note that reads, 'I go to Watson's Bay commit suicide. If unhappy, go to suicide. Remember, don't have children'. ${ }^{10}$ 'Don't have children' testifies to and admonishes a motherhood that is too painful to be lived. As the mother walks into the sea at sunset she cries 'I do everything good. I want finish suffering' ${ }^{11}$ As Yen struggles to make sense of this, ${ }^{12}$ she has to come to terms with issues of guilt and responsibility that she feels at a personal level (upset, anger, the feelings of not being wanted about which Carolyn Steedman has written so eloquently and bitterly), ${ }^{13}$ even while the performance invites our consideration of these at a political level. Or rather, it is the mobilization of the personal, the emotional level that charges the political.

In Chinese Take Away the stage is set with a backdrop of red silk in the shape of a house that has one window in it for slide projections. This serves as a 'window' onto mother-child relations as Yen's biographical searches 'reconceive' them. In brief, the maternal experience Yen inherits as daughter is one in which mother-child relations are marked by histories of colonialist and patriarchal violence. Yen cannot think mother outside of the ancestral chain that 'sells', 'bargains' each child's (mother's) life away. What this exposes is some of the limitations of Western feminist approaches to subjectivity with respect to the maternal. In an early work, About Chinese Women, Kristeva writes of the limits imposed by the two extremes of Western women's complicity with or their refusal of the symbolic: either 'speaking' the symbolic (masculine, paternal), or a silenced, 'eternal sulk before history' for not being allowed 'in', accompanied by the possibility of an 'escape into smug polymorphism'. ${ }^{14}$ Kristeva's self-reflexivity is desirable in the interests of trying to 'see' differently, and interesting for the ways in which she notes and rehearses the primacy of sexual difference in the Western frame before she gets to 'know' Chinese women. Yet it is also problematic for the way in which she proposes some identification with the symbolic in order to have a voice within it which is not complicit but brings to it an 'echo of our jouissance, of our madness, of our pregnancies'. ${ }^{15}$ The problem here lies with the 'our': there are those mother-child relations, as Take Away shows, that are so damaged by the symbolic that semiotic jouissance is necessarily a matter of foreclosure. A semiotic 'undoing' of the symbolic which invites 'us' to celebrate is instead undone through its very failure to include.

On a personal note, seeing Chinese Take Away 'shocked' me, moved me to reconsider thinking the maternal through an economy of the feminine (largely derived from French feminist thinking), which in other, strictly Western, contexts has proved useful to me. For instance, in analyses of Bobby Baker's solo performances of the 'unruly' mother I have argued the (painful) pleasures of being in the company of the mother who 'misbehaves' 


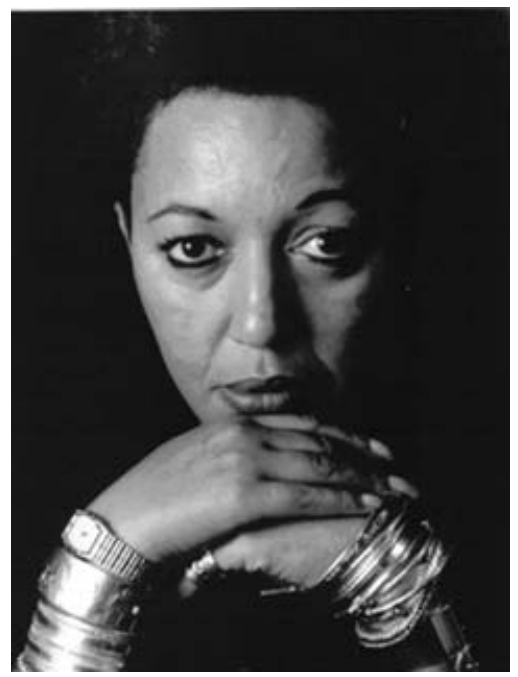

FIG. 2 SuAndi. Photograph (c) Robert Taylor (www.taylor-photo.co.uk).

and does not keep to her 'proper' place, for whom such 'misbehaviour' is a source of celebratory abjection. ${ }^{16}$ Further, I also felt the ways in which Chinese Take Away points to the limitations of antiessentialist rejections of identity categories when this may, as Take Away illustrates, be a an essential source of resistant survival. Torn from her Chinese, Asian 'roots' (except for a fragile connection through letter-writing over the years to her third sister, which is her only way of letting out the pain she is otherwise forced to live), Yen's mother is cut off from cultures of marital and maternal resistance - the stories, for example, of the silk-weaving communities of marriage resisters. ${ }^{17}$ Moreover, in her particular, painful circumstances she does not have the will to 'play', masquerade or perform maternal norms to reiterative subversive effect. Rather, it is motherhood that performs its own violent, global cover up, that successfully hides local histories of racial, economic and domestic violence. ${ }^{18}$

\section{White mother/black histories: The Story of $M$}

Seeing Chinese Take Away moved me to think about my own feminist attachments to Western maternal thinking, and, in doing so, brought me back to a solo mother-daughter show that I have known over a much longer period of time: SuAndi's The Story of $M$. I want to set SuAndi's solo 'beside' Yen's Take Away as a way of heightening the emotionalpolitical 'space' of this essay; 'staging' accounts of these two shows together, alongside each other, is again to be moved to think the maternal inside, rather than outside (white), histories of race, class and nation.

In The Story of $M$, black British performance artist SuAndi performs the story of her mother, Margaret Josephine Andi. Staged in a minimalist hospital setting with a white screen onto which are projected slides, snapshots from Margaret's life, SuAndi performs

\section{CAMBRIDGE JDURNALS}


her mother's story in an intimate, 'having-a-chat' or gossip style of telling. The story that is told is one of Margaret's lonely and loveless childhood, and the hardship and poverty she endured raising her own two children. M's story links the autobiographical to a working-class history of life in the mid-twentieth-century English industrial north in the cities of Liverpool and Manchester. Above all, The Story of $M$ testifies to a racist Britain: the prejudice and brutality of the police force; Margaret's children (a boy and a girl) subjected to racist name-calling, treated as 'dirty' on account of being black; her daughter excluded from performing in an all-white pantomime when 'she didn't blend in with the rest of the kids' ${ }^{19}$

Towards the end of the show, SuAndi breaks the fiction of playing Margaret: shatters the 'I' that was Margaret to establish herself as SuAndi. She announces, 'this was the story of $\mathrm{M}-/ \mathrm{M}$ for Margaret/M for Mother,/And now $\mathrm{M}$ for Me./ And my name is SuAndi'. ${ }^{20}$ Two final slides project 'Margaret': first her death certificate and then a photograph. For many spectators, white spectators in particular, it comes as something of a shock to realize that Margaret is white and not black, and audiences tend to be visibly stunned by the white mother smiling to camera, shocked out of the way in which they have presumed to already know Margaret as a black mother. I have seen $M$ on different occasions and have got to know SuAndi in a way that has enabled me to get 'close' to this story - but even knowing as I do, I still feel the effects of Margaret's whiteness.

Where does this (false) sense of knowing come from? As a character monologue $M$ observes the conventions of performer-role identification: the spectator believes, according to theatrical convention, in the 'oneness' between character and performer. However, in that 'oneness' SuAndi's playing of $M$ is also breaking theatrical convention and feminist expectations of the already knowing. In performance terms, despite an increase in efforts, especially by multiracial companies, to cast colour-blind, the dominant way of casting and 'seeing' performers is by stereotypical associations of skin colour. An audience 'sees' a black mother because the performer/daughter is black. In terms of feminist thinking this way of seeing is also compounded by the legacy of white feminism speaking for black women, or more recent preoccupations with how the 'other' speaks. ${ }^{21}$ Simply put, an audience listening to M's story hears black because it is exceptional for a black woman to speak a white woman's experience. In this way $M$ is performed as a story that feels familiar, makes us feel 'at home', at the same time as it 'loosens' and makes strange.

Given this radicalization of performance convention and feminist expectation, what comes into view? The realization that Margaret is white, is 'mixed in along with all those Africans', moves the spectator to another place of (political) thinking and feeling. Getting to know M, getting close to $M$, is not an affirmation of (white) mother-daughter 'sisterhood'. Rather it requires a letting go of this paradigm to see the mother as 'messed up', 'mixed in' with black diaspora histories. While SuAndi's biological connection to Africa exists through her Nigerian father, it is her white mother who teaches her to love and be proud of her blackness. A psychic connection to the mother is not prior to, but maps with, racial histories and identities.

My argument for $M$ can be further supported by drawing on a mother 'story' by activist, artist and writer Coco Fusco in her introduction to the essay collection The Bodies 
that Were Not Ours. To preface the collection Fusco comes back to her mother, opening with a story told to her by her mother, an anti-slavery story from their Cuban family history. Fusco's point is that because 'the difference that marks the subaltern subject first made itself present to me through my mother's look and voice, my connection to it is as emotional as it is cerebral. It is historical memory that I live as both a psychic and bodily experience'. ${ }^{22}$ Moreover, mixing the personal and autobiographical with the theoretical, notably her explanation of 'subaltern subjectivity' taken from Hortense Spiller, Fusco argues persuasively for a personal link to colonial histories that is 'not in synch with the euphemistic characterizations of disembodiment that dominate the present moment'. ${ }^{23}$ Rather, Fusco attends to subaltern subject-identities that 'loosen' the Freudian Oedipal model through histories that are marked by the traumas of black experience, of slavery. ${ }^{24}$

Similarly, in $M$, the maternal originates in histories, stories of race, class and nation. Listening to M's stories means getting up close to racism, being touched by the mother figured through the flesh of the black daughter whose body, whose skin, let us not forget, is the body that holds or is marked by the stories, the memories, the scars of being told she could not be in the all-white pantomime; whose skin is the black body that astonished teachers by being able to do ballet and is the body that was called 'dirty' by the parents and children of white families. The intimacy, the familiarity, of the mother-daughter paradigm is put to work, to getting across histories and experiences that are otherwise hidden. $M$ makes us love her, makes us laugh - but also catches us laughing, when perhaps we should not. She gives comfort and she discomforts, 'keeps', 'withholds' her 'whiteness' as an invitation to see the mother otherwise, keeps the primary (white) attachments to the mother at a distance so that histories of class, race and nation are positioned as central rather than parenthetical to subject formation.

In the closing moment of her performance, as she steps out of the mother role to 'become' herself, SuAndi often cries - has her own moment of grieving. Audiences for both $M$ and Take Away, as I have experienced them, are for the most part moved to tears, affected by the identification with the loss of the mother. As a spectator, whatever an individual emotional response might be to the shows, what is also affecting is to be moved by the grief of others. In her essay collection Undoing Gender Judith Butler claims grief, loss, as one of the transformative ways of 'becoming undone'. While grief is generally considered to be a private, solitary matter, Butler argues instead that 'it exposes the constitutive sociality of the self, a basis of thinking a political community of a complex order'. ${ }^{25}$ With this in mind Butler asks, is there 'something to be gained in the political domain by maintaining grief as part of the framework by which we think our international ties? ${ }^{26}$

I want to pursue Butler's question in connection with a third and final performance, Kazuko Hohki's Toothless. If my argument so far has been to position Take Away and Mas emotional-political solos that variously contest (white) European and North American ways of knowing the mother, I want to consider Toothless beside these two shows in order to reflect on mother loss, 'grief' as productive for 'international [feminist] ties'. 


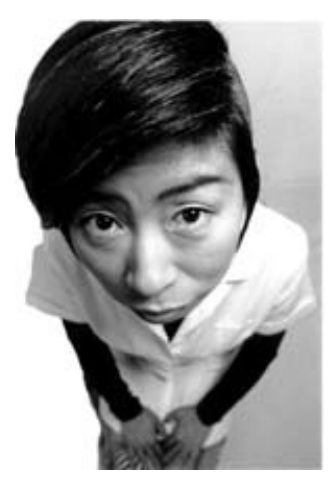

FIG. 3 Kazuko Hohki, Toothless. Photograph (c) David Bennet.

\section{Becoming undone: Toothless}

In Toothless, Kazuko Hohki presents her mother's life in the 'space' of her death. ${ }^{27}$ As a religious entertainer, Hohki's mother delighted audiences with her comic clowning her imaginary tightrope walking or plate-spinning (imagine you can see the plate and you see God). Hohki is a comedienne of a different kind: punk performance artist, musician, animator whose more secular interests include an obsession with English cultural heritage. ${ }^{28}$ Toothless concentrates on that brief but drawn-out moment of a life ending before its time, a time in which all other matters (world events, friendships, loves, families, the ordinary everydayness of living) cease to matter. The awe-full-ness of that moment does not make its mark on the world. 'When my mother died,' SuAndi says, 'the world did not stand still. Nothing stopped, changed to note her passing' ${ }^{29}$ But for those personally involved the effects are monumental as ordinary lives are undone through loss.

In Toothless 'becoming undone' is an aesthetic and compositional consideration. Visually, as a solo performer, Hohki is always in relation to the other, the mother, whose presence is encoded variously through video footage projected on to the white screen, the recurring, haunting screening of her empty armchair, or the grotesque mannequin, slumped alongside Hohki in a wheelchair. One might be tempted to argue that the proximity of the maternal proposes an at-oneness between mother and daughter. Radically undercutting any such suggestion, however, is the way in which these two 'bodies', two selves, do not think and feel as one, but each works variously and differently on the other: each emotionalizes the other in ways that take 'one' by surprise. Each produces states of feeling that refuse an idea of self-containment. For example, there are 'mirroring' sequences in which Hohki (live) imitates the imaginary tightrope-walking of her mother on-screen. Except the mirroring is not synchronized: neither matches the other exactly, rhythms are quite different and each performer has their own, individuated moments of being caught off balance or finding balance hard to maintain. The tightrope 'trick', like the plate-spinning, had a spiritual purpose for Hohki's mother: to believe in the perfection of the self is to see the perfect path being walked. However, to be 'contained', bound by strength, perfection, happiness, as the mother believes, is undone 
though illness. While believing in her own vision has kept her apart, from being close to others, this distance is necessarily transformed by her illness. As her body becomes an abject 'house of horror' (a body that bleeds everywhere, cannot be kept clean; a face grotesqued by illness, enlarged about the mouth whose swollen tongue gives her the appearance of having three lips) she cannot but choose to get closer to others.

Toothless suggests that to remain untouched by the other can only be a matter of pretending. For instance, when Hohki is first called back to Japan (by her father and brother) on account of her mother's illness, and it is too painful for her mother to speak because of the cancer that is spreading in her gums, instead of getting a hug or a kiss, Hohki gets a letter: 'Welcome back. It's difficult for me to talk, so that's why I'm writing this ... Please don't worry. I'll be alright very soon'. What follows is an elaborate pretence of each woman smiling at the other for half an hour, face to face, like two samurai warriors with smiles for weapons, with neither being able to cope with the emotion of the other.

The difficulty of speaking also implies 'careful' listening. Video footage in the opening sequence of Toothless records the mother trying to make a speech at a religious congress without her false teeth in (she finds the teeth increasingly uncomfortable to wear because of her gum trouble, and she is therefore constantly taking them out, putting them down and losing them). Speaking 'toothless' is a powerfully funny image of vulnerability: the face is not quite right, 'proper' for speaking in public; the words are 'misshapen', harder to hear in a toothless mouth, partially hidden by the hands that move up to the lips to cover the 'loss'. Similarly, Hohki jokes with her audience about her English, asking if they find her heavily accented English words 'charming', as a way of pointing out that she will never be able to speak English 'properly', no matter how long she lives, works or performs in the country, on account of racial, physical difference. An Asian mouth is one, she explains, in which the teeth stick out rather than are tucked in. Hers is not an 'English' mouth. The mouth without teeth, the teeth that physically shape how we speak, each of these makes demands on the one who listens - requires, if one is to truly listen, working harder for the other.

To be working for, listening to, the other brings me back to the issue of undoing, where such a listening means hearing, being touched, undone by the other. In the theatrical encounter with Toothless one gets involved with the grief: we are not at a loss, we are (imaginatively) in it. Being in it means caring about and caring for the other. This may bring us close to losses of our own that we have already faced and those, perhaps harder still, we hardly dare imagine facing. Those personal connections to loss, however, are also felt in the international mix of Hohki's autobiographical performancemaking, which insists on a caring for and a caring about others that are close and at a distance. Working in England Hohki is at a distance from and yet close to home, as captured in the delightful line about her mother: 'She was so wonderful that I had to leave the country'. Involved in her mother's terminal illness, Hohki flies between Asia and Europe, Japan and Britain, transforming those maternal ties through intercontinental flight, movement. Caring for and about is personal at the same time as it is international. Care and responsibility for the elderly is generally a 'burden' that is expected to fall on the daughter, but Toothless mobilizes that paradigm to ask where the responsibilities of 
caring should lie - locally and globally - and, importantly, to present the crisis of caring when matters are taken out of our control. ${ }^{30}$

In an animation sequence, Hohki illustrates the uncontrollable impact of the Second World War on her mother's personal life. Hohki's mother marries but does not have children straight away - instead she has a war. A paper plane drops several bombs. After the war a paper mother 'drops' two children. Imaging the juxtaposition of violence and the maternal, Hohki presents the idea of terrorized violence, loss and grief (of the kind we are currently, frighteningly, seeing far too much of): the moment that more often than not results in (national) boundaries being reinforced rather than broken down, in which the one is cut off from the other as 'bonds' of enmity are formed. Seriously, Hohki jokes, this is the political bit of the show that is not really part of the story. We do not really need to pay attention. Though this of course brings our attention to the politics of the 'gap' between lives as we personally attempt to determine or live them and the conditions of being in the world which necessarily mean that lives are controlled and shaped (and destroyed) by others.

This brings me back to the possibilities that Butler speculates might come from remaining open to grief: grief as 'a resource for politics' in which 'return[ing] to a sense of human vulnerability' might help with 'our collective responsibility for the physical lives of one another'. As Butler elaborates,

There is a more general conception of the human at work here, one in which we are, from the start, given over to the other, one in which we are, from the start, even prior to individuation itself, and by virtue of our embodiment, given over to an other: this makes us vulnerable to violence, but also to another range of touch, a range that includes the eradication of our being at the one end, and the physical support for our lives, at the other. ${ }^{31}$

The idea of being 'given over to the other' is one that Butler compares to a state of infancy, 'a necessary dependency, one that we never fully leave behind'. If, as Butler claims, there is 'no way to argue away this condition of a primary vulnerability', ${ }^{32}$ then coming back to the mother is not a proposal for a semiotic oneness, an imaginary wholeness, but to an idea of always being given over to the other.

Hohki visualizes this through her mother's transformation into a human planet. She sings the lyrics 'some enchanted evening, I might see a stranger', while on the screen to the side of her, alien space figures come into her mother's house that, Tardis-like, appears to be lifting off into space, tilting and shuddering. On the one hand this gives visual expression to the way in which a body that, when living, is warm and familiar to us, becomes 'alien' and cold in death. ${ }^{33}$ On the other, the idea of the mother as a human planet is one in which mother and alien fuse: the one and the other, self and 'stranger', become a necessary, life-sustaining, live-evolving, primary, dependent part of each other. In brief, mediating between the technologies of the screen and the liveness of the body, the interplay of histories and futures, Hohki's Toothless imagines the transformative possibilities of living with loss, of 'becoming undone' in a way that may bring us closer to (distant) others. 
By performing the loss, the death of the mother, each of these three solo shows creates an emotionally charged, critically transformative space. The absent mother, a 'deathpresence' screened and haunting the live body of the daughter, is both a familiar and at the same time an 'alien' body. 'Coming back to mother' tells a story that offers a 'universal' point of entry or identification, at the same time as it refuses the (self-)absorptive space of the maternal melodrama, emotionalizes reflexively to move to a politics of knowing the maternal otherwise. Chinese Take Away and The Story of M perform the personal, biological, biographical attachment that each daughter has for her mother, in ways that detach from the (white) Western Freudian paradigm of mother-child relations, and reattach to public histories of race, class and nation. Toothless exemplifies the feminist political possibilities of such reattachments, of a 'primary vulnerability' that resides in necessarily having our lives given over, made over, to alien (m)others. As an audience, to be moved by the grief, the loss of the mother, in each instance, is also to become attached, receptive and open to maternal histories and stories beside(s) our own. In the case of Hohki and SuAndi, getting closer to these stories has involved getting closer to the artist and to her work; with Yen the connection was made through an international women's theatre network. ${ }^{34}$ In all cases the possibility of forming 'attachments' through theatre needs to be stressed - this at a time when it is no longer possible to rely on feminism (a feminist movement) to make the connections for us.

Finally, as death stories, suicide, cancer stories, these performances operate in the realm of what Sedgwick, herself a cancer patient, describes as the difference between knowing and realizing: the difference between knowing and really knowing one is going to die. ${ }^{35}$ In such circumstances, Sedgwick observes, 'whatever else we know, we know there isn't time to bullshit'. ${ }^{36}$ In the emotionally charged death space of these mother solos the urgency of really knowing otherwise makes itself felt. Coming back to the mother is put to work in the interest of getting to know 'other' psychic, social and cultural geographies of the maternal, rather than the mother that is taken, mistaken, for 'our' (selfish) own.

NOTES

1 I would like to thank the Arts and Humanities Research Council for the funding of the Women's Writing for Performance Project (2003-6), without which this article would not have been possible.

2 For further details of the Festival see the collaborative essay by myself, Gerry Harris and Lena Šimić,

"“It is Good to Look at One's Own Shadow": A Women's International Theatre Festival and Questions for International Feminism', in Elaine Aston and Geraldine Harris, eds., Feminist Futures? Theatre, Performance, Theory (Basingstoke: Palgrave Macmillan, 2006), pp. 169-89. This also details the beginning festival moment, as I develop it here, about rethinking the maternal.

3 For details of the Magdalena project see Susan Bassnett, Magdalena: International Women's Experimental Theatre (Oxford: Berg, 1989).

4 In Looking for the Meaning Adams storytold the death of her mother as a way of coming to terms with her own experience of ageing, while Rasmussen's performance looks back over the life of her elderly mother who is now suffering from dementia.

5 Eve Sedgwick, Touching, Feeling (Durham: Duke University Press, 2003), p. 1. Briefly, through a discussion of affect, pedagogy and performativity Sedgwick argues for a 'step to the side of antiessentialism', for the need to think beyond the versions of what we already know, or what we have already learned to look for. Sedgwick asks what we might be able to see, learn or think 'otherwise' if we 
are prepared to relax our grip on 'the hygiene of current antiessentialism' (p. 111) or are prepared to loosen up on the anxiety of absolutely, resolutely needing to be antiessentialist in our thinking and theorizing.

Ibid., p. 8.

Jill Dolan, 'Performance, Utopia, and the "Utopian Performative”, Theatre Journal, 53 (2001), pp. 455-79, here pp. 456-9.

At each point in the performance that this detail is revealed it is accompanied by an image on the screen of a child's eyes, peering out of a basket, a child taken to market whose gaze looks anxiously back at the 'viewer'. See Anna Yen, Chinese Take Away, in Don Batchelor, ed., 3 Plays by Asian Australians (Brisbane: Playlab Press, 2000), pp. 32-71, Scene 5, p. 46 and Scene 21, p. 66.

See Scene 10, 'Mother Arrives in Australia', Chinese Take Away, pp. 51-2.

Yen, Take Away, Scene 20, p. 62.

Yen, Take Away, Scene 22, p. 69.

Her fight is physically embodied as a struggle between 'warrior woman' and 'crying child', performed through physical movements taken from the Wushu Sword form. See directions for Take Away, Scene 12, p. 53 .

3 Carolyn Steedman, Landscape for a Good Woman: A Story of Two Lives (London: Virago, 1986). Steedman's seminal account examines the way in which her working-class mother's life shaped her childhood, and, in particular, ways in which her childhood perceptions were coloured by feelings of being unwanted: 'There was nothing we could do to pay back the debt of our existence. "Never have children dear," she said; "they ruin your life" (Landscape, p. 17).

4 Julia Kristeva, About Chinese Women (London: Marion Boyars, 1986; first published 1974), pp. $37-8$. 'Smug polymorphism' could, for example, be taken as a way of characterizing an earlier (second-wave) phase of cultural feminist theatre-making whose aesthetics, composition and practice were largely concerned with 'translating' ideas, sourced by French feminist theory, into a practice that imagined a 'return' to the pre-Oedipal or Imaginary Mother.

5 Kristeva, About Chinese Women, p. 38. To this I would also add the more recent general criticism of Kristeva's approach to knowing 'about Chinese women' that Sarah Ahmed presents in Strange Encounters: Embodied Others in Post-coloniality (London: Routledge, 2000). Ahmed's caution is that in About Chinese Women, where Kristeva applies an approach that relies on becoming a stranger to oneself, the risk is that one might create a new 'universal': a 'new community of the "we" is implicitly created. If we are all strangers (to ourselves), then nobody is' (Ahmed, Strange Encounters, p. 73). See, for example, Elaine Aston, 'Making a Spectacle Out of Herself: Bobby Baker's Take a Peek!', European Journal of Women's Studies, 11 (August, 2004), pp. 277-94.

In Scene 14 Yen tells the story of the marriage resisters, women from the silk factories who formed all-female societies that vowed not to marry. 'It was said that if a Marriage Resister was forced by her family to wed, she would sew herself into her underclothes on the wedding night' (Yen, Take Away, p. 55).

8 In a scene in which Anna enacts one of her best memories of her father, an occasion when he took the family to see a Chinese acrobatic troupe, she gives a performance of 'The Other Anna Yen'. Yen explains that she was told about another performer called Anna Yen by a woman researching British music hall. All that was known about her was: 'Anna Yen, three eggs on a Chop stick' (Take Away, Scene 16, p. 58). This 'other' Anna Yen is presented by Yen as playing the English music hall, performing a bawdy, lively, raucous routine. Then she stops performing, marries an Englishman and disappears into an 'English pastoral landscape': 'I was so very proud of my children. They didn't look Oriental' (p. 59). 'It was a quiet life', the other Anna Yen concludes, as '[h]er vanity case suddenly opens and china plates and cups spill out, breaking noisily' (p. 59). The Gestus of the (feminine) vanity case that spills and breaks its (domestic) china indexes the violent containment that operates in the name of mother.

9 SuAndi, The Story of $M$, in SuAndi, ed., 4 For More (Manchester: Black Arts Alliance, 2002), pp. 1-18, here p. 16.

\section{CAMBridge JDUNALS}


20 SuAndi, The Story of $M$, p. 18.

21 See, for example, Ahmed's chapter 'Knowing Strangers' in Strange Encounters, pp. 55-74.

22 Coco Fusco, ed., The Bodies That Were Not Ours and Other Writings (London: Routledge, 2001), pp. xiv-xv.

23 Ibid., p. xiv.

24 Specifically Fusco writes: 'As cultural theorist Hortense Spillers so eloquently points out, the annihilation of family structure, the mutilation, and the severing of the body from will are real traumas at the root of black experience in the New World' (Bodies, p. xiv).

25 Judith Butler, Undoing Gender (London: Routledge, 2004), p. 19; added emphasis.

26 Ibid., p. 23.

27 There is no published text of Toothless. I am indebted to Kazuko Hohki for a video recording of the show.

28 One of Hohki's current performance projects, for example, is exploring Japanese women's obsession with Wuthering Heights, which she has been researching through a 'Time and Space' Fellowship held with us at the Nuffield Theatre, Lancaster University. It is through the fellowship arrangements that I have been getting to know Hohki's work.

29 SuAndi, The Story of $M$, p. 17.

30 One of the ways that Hohki presents this is through the narration of her flight back to Japan for the funeral, and the comic telling of the various obstacles and delays attendant on international travel that variously militated against her attempts to reach her mother's body.

$31 \quad$ Undoing Gender, p. 23.

32 Ibid., p. 24.

33 Hohki experiences an urgent need to see her dead mother's body, to see her for one last time. Yet when she gets to see the body it is not how she expects it to be: the body has no life, is cold to touch, has no presence.

34 See note 28 on getting to know Hohki's work. SuAndi has also forged friendship and research links with us at Lancaster, while the possibility of knowing about Yen's performance arose out of the Transit Festival, Magdalena Project network.

35 Eve Sedgwick, Touching Feeling (Durham: Duke University Press, 2003), p. 174.

36 Ibid., p. 149.

ELAINe ASTON is Professor of Contemporary Performance at Lancaster University, UK, where she teaches and researches feminist theatre, theory and performance, a field in which she is widely published. Her authored studies include An Introduction to Feminism and Theatre (1994), Caryl Churchill (1997/2001), Feminist Theatre Practice (1999) and Feminist Views on the English Stage (2003). She has co-edited four volumes of plays by women and, with Janelle Reinelt, co-edited The Cambridge Companion to Modern British Women Playwrights (2000). Her most recent publication, co-edited with Gerry Harris, is Feminist Futures? Theatre, Performance, Theory (2006).

\section{CAMBRIDGE JDURNALS}

